\title{
First record of Cryptopodia angulata H. Milne Edwards and Lucas, 1841 from Saurashtra coast, Gujarat, India (Decapoda: Brachyura: Parthenopidae)
}

\author{
Jigneshkumar N. Trivedi and Kauresh D. Vachhrajani* \\ The Maharaja Sayajirao University of Baroda, Faculty of Science, Department of Zoology, Division of Environment and Toxicology, Marine \\ Biodiversity and Ecology Lab, Vadodara, 390002 Gujarat, India. \\ * Corresponding author E-mail: kauresh@gmail.com
}

\begin{abstract}
Cryptopodia angulata is reported for the first time from Saurashtra coast of Gujarat state. One adult female was found in trawl catch near Sutrapada village of Saurashtra coast on January, 2012. Although the species is not common in Indian waters, this species has been reported from the south east coast of India. This is the first report from Saurashtra coast.
\end{abstract}

The state of Gujarat harbors the longest coast line in India which is $1,663 \mathrm{~km}$ long. The marine fauna of state is very rich in diversity (Pillai and Patel 1988; Apte 1998; Venkataram 2005). The brachyuran fauna of Gujarat is least studied and except the scattered work on the South Gujarat coast, a few locations on Saurashtra coast and the Gulf of Kachchh by Chhapgar (1957), Chandy (1973) and recently by our group (Pandya and Vachhrajani 2010; Trivedi et al. 2012) no specific document on the status of brachyuran crabs is available. The intertidal area of the Saurashtra coast is mostly rocky with patches of sandy and muddy shores. The width of the intertidal area ranges from $50 \mathrm{~m}$ to $300 \mathrm{~m}$ and apparent habitat zonation is observed which supports different kinds of animal community (Vaghela and Kundu 2012). During the survey of brachyuran fauna of Saurashtra coast one adult female specimen of Cryptopodia angulata H. Milne Edwards and Lucas, 1841 was collected in trawl catch. The specimen was preserved in $10 \%$ formalin and its taxonomy was confirmed to species level using various references (Sethuramalingam and Ajmal Khan 1991; Chiong and Ng 1998; Jeyabaskaran et al. 2000; Ravichandran et al. 2010). The study area is not included under any notified or protected regions as well as the species under consideration is not listed/ categorized for protection, and therefore, no permission from any defined authority was required for collection of this species. The specimen was deposited in the museum of Department of Zoology (ZL-AR-CR-35), The Maharaja Sayajirao University of Baroda, Vadodara, Gujarat, India.

Cryptopodia angulata $\mathrm{H}$. Milne Edwards and Lucas, 1841

One adult female (CL $52.76 \mathrm{~mm}$, CW $32.30 \mathrm{~mm}$ ) was collected from trawl catch at 25-27 m depth near Sutrapada village $20^{\circ} 49^{\prime} 53^{\prime \prime}$ N, 70²9'17" E on Saurashtra coast of Gujarat state. The specimen was collected by Jignesh Kumar Trivedi in 23.i. 2012 (ZL-AR-CR-35).

The species has wide distribution including Maldives, Sri Lanka, Singapore, Australia and Gulf of Thailand. In India the species is recorded from west coast (Alcock
1895; Chhapgar 1957) and south east coast (Ravichandran et al. 2010). Carapace is broader than long, pentagonal and convex in shape, the edges of the carapace are dentate and harbors curved spine at all angles, the lateral margins of the carapace are large and conceal the abdomen and ambulatory legs beneath it, the shape of the teeth range from simple to bifurcate. Two spines are observed at the centre of the posterior margin of the carapace, second spine is present in front of both the anterolateral spines, the dorsal surface of carapace is granulated while ventral surface is smooth, deep triangular depression is observed at the centre of the carapace and branchial, cardiac and gastric regions are elevated, the margins of the triangular depression are granulated and ridges of the granules start from the apex of the triangular shape and end at the base of the rostrum on either side, orbits and eyes are small and round, the surface of the third maxillipeds is smooth.

Chelipeds are granular and robust, palm contains denticules in anterior and posterior margins, five prominent teeth are present on the anterior margin of palm, the carpus of the chelipeds is semi globular, merus is flat and harbors wing like expansions at the distal end with denticulate pattern on upper and lower margins, fingers are short and smooth.

Ambulatory legs are slender and smooth, the first pair of legs is longest, the upper margin of the merus is denticulate while lower margin is crenate, and dactylus is strongly crenate on both margins (Figures 1 and 2).

Cryptopodia angulata is not common in Indian waters. The species mostly prefer bottoms of sand and broken shells within the depth of 25 to $30 \mathrm{~m}$ (Chhapgar 1957). The species was first recorded by Alcock (1895) from Orissa and Malabar Coast of India . Chopra (1935) has recorded the species from Sandheds, West Bengal, while Chhapgar (1957) has reported the species from Gulf of Kutch, Gujarat. Except these records Banu and Nurul-Huda (1987) and Tirmizi and Kazmi (1983) have recorded the species from Karachi, Pakistan and Penang, Malasia, respectively. Recently Fatemi et al. 2012 and Ravichandran et al. (2010) 
have reported the species from Oman Sea and Calimere coastal region of South east coast of India, respectively. Although, Cryptopodia angulata and Cryptopodia echinosa are very similar morphologically certain distinctive characters have been described: the carapace is more triangular in shape and the degree of granulation on its surface is high in Cryptopodia echinosa while the carapace of Cryptopodia angulata is more pentagonal in shape, the branchial, gastric and cardiac regions are strongly inflated and gastric region is more deeper in Cryptopodia echinosa than in Cryptopodia angulata (Chiong and Ng 1998; Fatemi et al. 2012).

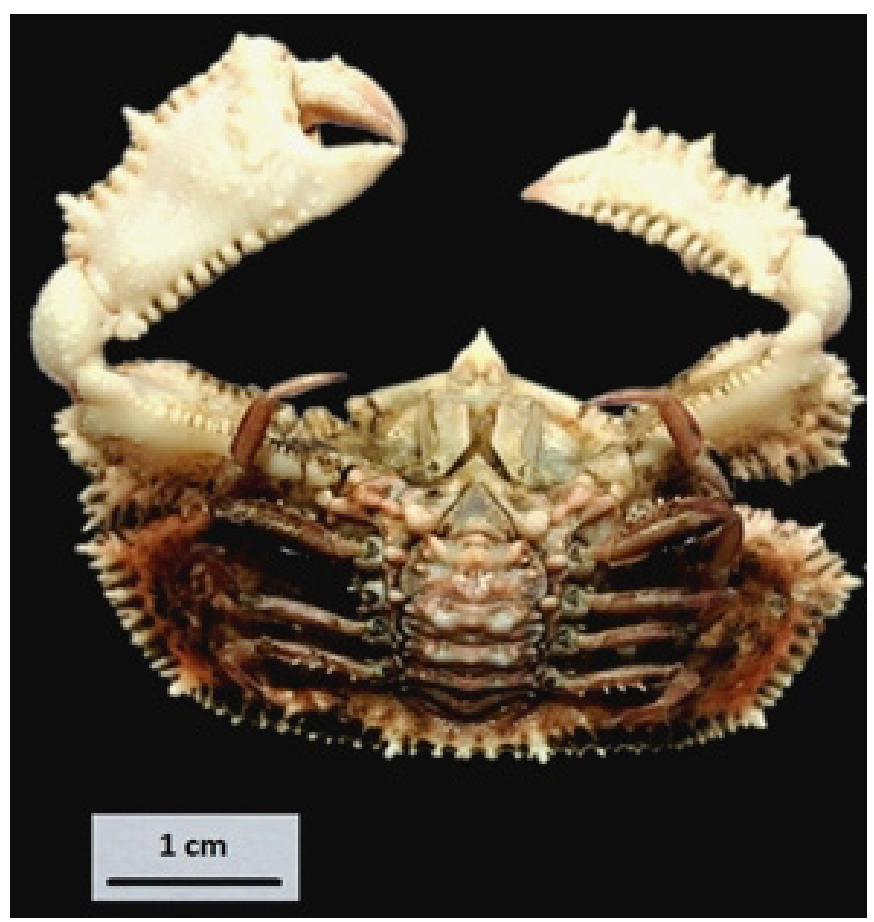

FIGURE 1. Cryptopodia angulata Ventral view (ZL-AR-CR-35).

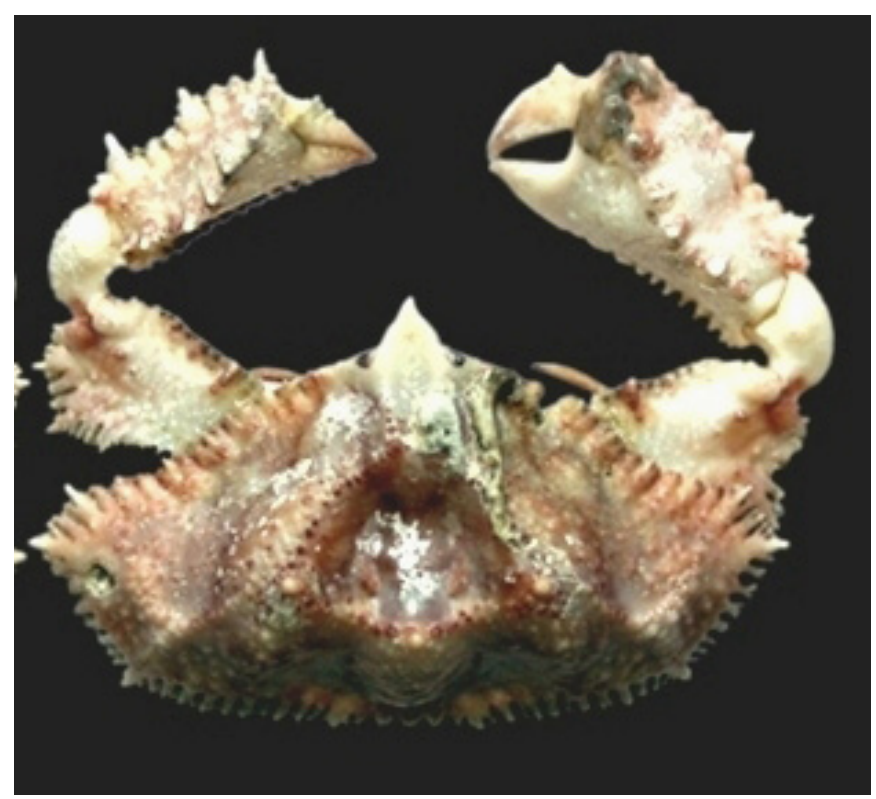

FIGURE 2. Cryptopodia angulata Dorsal view (ZL-AR-CR-35).
The present record of Cryptopodia angulata is the first report from Saurashtra coast, Gujarat, India. The brachyuran fauna of this particular area is not studied well and present study is part of the exploration.

ACKNOWLEDGMENTS: The authors are thankful to local fisherman community and Kalpesh Gohel and Vishal Pankhaniya for their help in field explorations.

\section{Literature Cited}

Alcock, A. 1895. The BrachyuraOxyryncha. Material for a carcinological fauna of India, No. 1. Journal of the Asiatic Society of Bengal 64(2): 157-291.

Apte, D. 1998. Book of Indian Shells. Mumbai: Bombay Natural History Society. 115 p.

Banu, Q. and K.M. Nurul Huda. 1987. New record of Cryptopodia angulata H. Milne Edwards \& Lucas (Parthenopidae: Decapoda: Crustacea) from Malaysian waters. Journal of Bombay Natural History Society 85: 646-647.

Chandy, M. 1973. New records of brachyuran decapods from the Gulf of Kutch. Journal of Bombay Natural History Society70(2): 401-402.

Chhapgar, B.F. 1957. On the marine crabs (Decapoda: Brachyura) of Bombay State. Part 1. Journal of Bombay Natural History Society 54(2): 399-439.

Chiong, W.L. and P.K.L. Ng. 1997. A revision of bucklers crabs of the genus Cryptopodia H. Milne Edwards, 1834 (Crustacea: Decapoda: Brachyura: Parthenopidae). The Raffles Bulletin of Zoology 46(1): 157-216.

Chopra, B. 1935. Further notes on Crustacea Decapoda in the Indian Museum VIII. On the Decapod Crustacea collected by Bengal pilot services off the mouth of Hoogley River. Brachynatha (Oxyryhncha and Brachyryncha) Records of Indian Museum 37: 463-514.

Fatemi, S.M.R., T. Valinsab, P.K.L. Ng and N. Ghotbeddin. 2012. First record of Cryptopodia echinosa (Crustacea: Decapoda: Brachyura: Parthenopidae) from Oman Sea. Marine Biodiversity Records 5: 1-3.

Jeyabaskaran, R., A.S. Khan and V. Ramaiyan. 2000. Biodiversity Project on Gulf of Mannar Biosphere Reserve. Parangipettai: Centre of Advanced Study in Marine Biology, Annamalai University. 175 p.

Milne Edwards, H. and H. Lucas. 1841. Description des Crustacés nouveaux ou peu connus conservés dans la collection du Muséum d'Histoire Naturelle. Archives du Muséum national d'Histoire naturelle 2: 461-473, plates 24-27.

Pandya, P.J. and K.D.Vachhrajani. 2010. Spatial distribution and substratum preference of brachyuran crab Macrophthalmus depressus (Decapoda: Ocypodidae) along the lower estuarine mudflats of Mahi River, Gujarat, India. Crustaceana 83: 1055-1067.

Pillai, C.S.G. and M.I. Patel. 1988. Scleractnian corals from the Gulf of Kutch. Journal of Marine Biological Association of India 30: 54-74.

Ravichandran, S., R. Anbuchezhian, K. Sivasubramaniyan and G. Rameshkumar. 2010. Expansion of occurrence of two bat crab (Crustacea: Decapoda: Brachyura: Parthenopidae) from the West to Southeast Coast of India. Biotemas 23(4): 163-167.

Sethuramalingam S.A. and S. Khan. 1991. Brachyuran Crabs of Parangipettai. Tamilnadu: Centre of Advance Study in Marine Biology, Annamalai University. 93 p.

Tirmizi, N.M. and Q.B. Kazmi. 1983. Carcinological studies in Pakistan with remarks on species common to the Red Sea and the Mediterranean. Bulletin of the Institute of Oceanography and Fisheries 9: 347-380.

Trivedi, J.N., M.K. Gadhvi and K.D. Vachhrajani 2012. Diversity and habitat preference of brachyuran crabs in Gulf of Kutch, Gujarat, India. Arthropods 1(1): 13-23.

Vaghela, A. and R. Kundu. 2012. Spatio-temporal variation of hermit crab (Crustacea: Decapoda) inhabiting rocky shore along Saurashtra coast, Western coast of India. Indian Journal of Geo Marine Science 41(2): 146-151.

Venkataraman, K. 2005. Coastasl and marine biodiversity of India. Indian Journal of Marine Sciences 34(1): 57-75.

RECEIVED: May 2012

ACCEPTED: April 2013

Published ONLINE: September 2013

EDITORIAL RESPONSIBILITY: Rodrigo Johnsson 